\title{
THE FREEDOM OF EXPRESSION VS. THE AUTHORITY OF THE COURT UNDER THE FIRST AMENDMENT TO THE U.S. CONSTITUTION AND ITS IMPACT ON THE GEORGIAN LEGISLATION
}

\author{
Tamar Avaliani, \\ Associate Professor, \\ Georgian National University SEU
}

\begin{abstract}
The present paper examines the case law of the European Court of Human Rights in relation to criticism of the Court, and the compliance of the Georgian legislation and the case law with international standards (U.S. and the case law of the European Court of Human Rights).

The article deals with the scope of the court's criticism under the First Amendment to the U.S. Constitution and its impact on the Georgian legislation. The paper analyzes the United States model of freedom of expression and compares it with the standards of the European Court of Human Rights. The study found that, similar to the U.S. model, the Georgian model of freedom of expression is based on the primacy of a neutral restriction on freedom of expression, which indicates a high standard of protection of freedom of speech. The Georgian constitutional standard for restricting freedom of expression in order to administer the process of justice smoothly, properly and effectively for a legitimate purpose is influenced by the "three-element" test developed in the Brandenburg case, and shares its essence. According to the Georgian model of freedom of expression, the restriction of freedom of expression for the legitimate aim of ensuring the independence and impartiality of the judiciary, should only be applied to the smooth and proper administration of justice, using the "Clear and Present Danger Test", involving its high probability. In terms of the court criticism, the Georgian model offers a substantive and content-neutral regulation, and prevents the restriction of the subject of expression. According to the standard of the Constitutional Court of Georgia, expressing an opinion on the activities of a judge is considered a constitutional right and enjoys a high value status. In order to protect the authority of the court, according to the standards of both the International and the Constitutional Court of Georgia, "pushing speech into falling victim to justice" and unjustifiably exercising interference is found inadmissible.
\end{abstract}

Keywords: Court, Criticism, Scope, Assessment.

\section{Introduction}

According to the standard of the Constitutional Court of Georgia, expressing a critical opinion regarding the activities of a judge is considered a constitutional right ${ }^{1}$, to which a judge, as a public figure, has an obligation to listen. The ongoing judiciary reforms and activities are a subject of increasing public interest, which might become a subject to criticism. The "marketplace of ideas" is the basis for the development of the individual and society, which is manifested in the pluralism of debating and dialogue. Therefore, it is important for judges to properly understand the merits of freedom of expression and its role in building a free society oriented on values.

\footnotetext{
${ }^{1}$ A ruling by the Constitutional Court of Georgia on the Case №2/482,483,487,502 "Political Union of the Citizens Movement for United Georgia", "Political Union of the Citizens Georgian Conservative Party", Citizens of Georgia Zviad Dzidziguri and Kakha Kukava, Georgian Young Lawyers Association, Citizens Dachi Tsaguria and Jaba Jishkari, "Public Defender of Georgia v. Parliament of Georgia”, April 18, 2011, Article 67.
} 
The article mainly analyzes the scope of criticism of the court (judge), observing the U.S. model of freedom of expression and its impact on the Georgian legislation.

The case law of the European Court of Human Rights on criticism of the court, as well as the compliance of the Georgian legislation and the case law with international standards are also examined.

\section{The "Clear and Present Danger Test" as a guarantee of freedom of expression}

The First Amendment ${ }^{2}$ to the United States Constitution is a supreme constitutional guarantee of protection of freedom of expression. The First Amendment to the Constitution stipulates in an imperative and absolute manner that the U.S. Congress is prohibited from passing legislation that restricts ${ }^{3}$ freedom of speech or the press. Regarding the content of the First Amendment, two questions need to be clarified: first, whether the constitutional regulation of the First Amendment applies only to the U.S. Congress, and second, whether the First Amendment is a record of an absolute nature, as suggested by the literal definition of the rule.

While it may seem at first glance that the First Amendment only applies to the Congress, this is not the case. The U.S. Supreme Court has clarified in a number of cases that the Congress referred to for the purposes of the First Amendment includes not only the legislature but also the entire federal government ${ }^{4}$. As the rights enshrined in the First Amendment to the U.S. Constitution are one of the cornerstones ${ }^{5}$ of the U.S. constitutional order, it is a binding constitutional rule for all branches of government. At the same time, although at first glance the First Amendment gives the impression of an absolute order and does not define the grounds for its restriction at the level of the Constitution, it is not of an absolute nature. Freedom of expression may be restricted in the public interest and in the face of clear and present dangers.

The doctrine of the First Amendment to the U.S. Constitution considers freedom of expression both as a goal and as a means. Freedom of expression is, on the one hand, the best means of personal development and, on the other hand, a precondition for the protection of other rights ${ }^{6}$.

The U.S. model of freedom of expression is content-neutrally regulated, indicating a high standard of freedom of expression. The First Amendment to the U.S. Constitution, for example, unlike the European Convention on Human Rights, does not contain grounds for restricting freedom of expression. They are established by the precedents set by the U.S. Supreme Court. Given the peculiarities of the Anglo-Saxon (common law) system, the grounds for restricting freedom of expression are formed from the specific court decisions. For example, the European Convention on Human Rights uses ${ }^{7}$ the "three-element test" to assess the restriction of freedom of expression. Pursuant to Article 10, Section 2 of the European Convention on Human Rights, a restriction on freedom of expression must meet the following preconditions: the restriction must be provided for by law; it must serve one of the legitimate aims enshrined in the Convention and the Constitution; Restriction must be necessary in a democratic society ${ }^{8}$. Since Section 2 of Article 10 of the European Convention on Human Rights comprehensively defines the grounds for restriction of freedom of expression, the European Court of Human Rights has no jurisdiction to extend the grounds for the restriction provided for in Article 10 of the Convention. Unlike the European Court model, in the U.S. the grounds for restricting the freedom of expression are fully

\footnotetext{
${ }^{2}$ First Amendment to the US Constitution, https://www.law.cornell.edu/constitution/first_amendment [1. s. 24.09.2021].

${ }^{3}$ Ibid.

${ }_{5}^{4}$ M. Okruashvili and I. Kotetishvili, 'Freedom of Expression', Volume I, Liberty Institute, 2005. p. 16.

${ }^{5}$ Ibid. 15

${ }^{6}$ A thesis by Eva Gotsiridze on "Freedom of Expression in the Context of a Fair Balance of Conflicting Values (in accordance with the jurisprudence of the European Convention on Human Rights and the Strasbourg Court)", International Law Institute - TSU, 2007, p. 398.

${ }^{7}$ Guide on Article 10 of the European Convention on Human Rights, Freedom of Expression, Updated - 31 August 2020, Council of Europe/European Court of Human Rights, 2021, pp.19-22.

${ }^{8}$ Ibid.
} 
determined by the court ${ }^{9}$. The "three-element test" of restricting the freedom of expression is also used by the Constitutional Court of Georgia in the assessment of the restriction of Article 17 of the Constitution.

The U.S. model of freedom of expression distinguishes between high and low values of expression. Expressing high value has the function of contributing to the value development of the society and brings benefits to it. The expression of low value, on the other hand, is anti-social in nature and is devoid of values.

The content-neutral regulation of freedom of expression in the United States suggests that the criterion for restricting freedom of expression under the First Amendment to the United States Constitution is the "Clear and Present Danger Test" ${ }^{\prime 10}$ developed by the Supreme Court of the United States. It is a content-neutral tool for restricting freedom of expression. The "Clear and Present Danger Test" is an important legal mechanism for balancing freedom of expression and the rights that are associated with it. The "Clear and Present Danger Test" was first used in the case Schenck v. United States ${ }^{11}$. The U.S. Supreme Court gave the Congress a wide range of considerations in interfering with freedom of expression in the Schenck case. According to former U.S. Supreme Court Justice Oliver Wendell Holmes, "the nature of any action depends on the circumstances under which the act was performed. Even the strictest protection of free speech will not justify a person who falsely shouts fire in a theatre and causes a panic"12. At the same time, "the key in any case is to determine whether the word used is uttered in circumstances that could create a clear and immediate threat, a threat to which protection falls within the authority of the Congress" ${ }^{13}$. The U.S. Supreme Court had for the first time established the doctrine of "Clear and Present Danger" in the Schenck case, which is still considered an important tool for interpreting the U.S. Constitution ${ }^{14}$. The shortcoming of the "Schenck test" was that it empowered the Congress to restrict the expression of a "dangerous tendency", as has been seen in various cases before the Supreme Court ${ }^{15}$. The "Bad Tendency Test" reflected in the case Abrams v. U.S. revealed the difference between the views of the Supreme Court Justices Oliver Wendell Holms and William Brandeis, having led to becoming a guarantee of freedom of expression. According to Holmes, regardless of the nature of political expression, only the apparent and immediate threat of real harm posed a power to the Congress to impose restrictions on freedom of expression ${ }^{16}$.In the case of Abrams v. U.S., Judges Holmes and Brandeis set some important standards in their differing views: In assessing restrictions on freedom of expression, the focus should have been on content-neutral regulation and expression could be restricted if it crossed the line between freedom of expression and violence. In the given case, Judge Holmes' definitions were based on the doctrine of "marketplace of ideas" and the doctrine of pluralism of opinion as a measure of truth ${ }^{17}$. In the case of Gitlow v. New York, which called for anarchy and coup d'état, the U.S. Supreme Court discussed the "dangerous tendency" and "bad tendency" tests along with the "clear and present danger" one, highlighting the fact that in this case, there was a specific punishment during the state of war ${ }^{18}$. Using the "Clear and Present Danger" test, Judge Holmes did not consider Gitlow's expression to be a clear and present danger.

The "Clear and Present Danger" test had filtered and a new standard for assessing restrictions on freedom of expression established in the 1969 U.S. Supreme Court case Brandenburg v. Ohio ${ }^{19}$, where it abolished the

\footnotetext{
${ }^{9}$ A thesis by Eva Gotsiridze on "Freedom of Expression in the Context of a Fair Balance of Conflicting Values (in accordance with the jurisprudence of the European Convention on Human Rights and the Strasbourg Court)", International Law Institute - TSU, 2007, pp. 404-405.

${ }^{10}$ A ruling by the Supreme Court of the United States on case No. 249 U.S. 47, Schenck v. United States, 1919. A ruling by the Supreme Court of the United States of America No. 395 U.S. 444 Brandenburg v. Ohio, 1969.

${ }^{11}$ A ruling by the Supreme Court of the United States on the Case No. 249 U.S. 47, Schenck v. United States, 1919.

${ }^{12}$ G. Tsulukidze, R. Kakabadze, V. Berekashvili, 'Freedom of Expression and Protection of Judicial Independence and Impartiality', Georgian Democratic Initiative (GDI) 2020, p.21.

${ }^{13}$ Ibid. 21.

${ }^{14}$ Case Law in the United States and Europe, Chapter II, Liberty Institute, 2005, p. 161.

${ }^{15}$ G. Tsulukidze, R. Kakabadze, V. Berekashvili, 'Freedom of Expression and Protection of Judicial Independence and Impartiality', Georgian Democratic Initiative (GDI) 2020, p.22.

${ }^{16}$ A ruling by the Supreme Court of the United States on the Case No. 250 U.S. 616 Abrams v. United States, 1919.

${ }^{17}$ Case Law in the United States and Europe, Chapter II, Liberty Institute, 2005, p. 32.

${ }^{18}$ A ruling by the Supreme Court of the United States on the Case No. 268 U.S. 652 Gitlow v. New York, 1925.

${ }^{19}$ A ruling by the Supreme Court of the United States on the Case No. 395 U.S. 444 Brandenburg v. Ohio, 1969.
} 
criminal liability of a member of the Ku Klux Klan for syndicalism. According to the "Brandenburg Test", freedom of expression cannot be restricted unless it is intended to provoke a clear and immediate challenge to an illegal act, and there is a high probability that such an act will take place. In contrast to previous rulings by the U.S. Supreme Court, the Supreme Court developed a "three-element test" of restriction of freedom of expression in the Brandenburg case, thus providing a solid basis for assessing a substantively neutral restriction on freedom of expression. According to the "Brandenburg Test", in order for the expression to be banned, there must be a direct and unequivocal call for a violation of the law; the expression, in its essence, should call for an immediate violation of the law, and there should be a high probability that the call will lead to an immediate violation of the law ${ }^{20}$. According to the standard developed in the Brandenburg case ${ }^{21}$, unless the above evidences are clear, even the preaching of violence and hatred is protected by the First Amendment to the U.S. Constitution. The introduction of the "Brandenburg Test" has expanded the scope of protection of freedom of expression and laid the groundwork for a substantially neutral model of U.S. restrictions on freedom of expression.

The threat of unjustified and arbitrary interference with freedom of expression is prevented by the third component of the "Brandenburg Test", regarding the high probability of the call to lead to an immediate violation of the law. This component of the "clear and present danger" obliges the person in authority to assert further evidence of the need to intervene in freedom of expression, thus reducing the risk of unjustified interference with the law and, on the other hand, diminishing the chances of encroachment of the content of expression $^{22}$. It should be noted that the use of the "clear and present danger" criterion provides a greater precondition for better protection of freedom of expression than the European criterion of "necessary in a democratic society" 23 , as the latter is a general rule allowing for wider interpretation and enables more interference into the content of freedom of expression.

The Georgian model of freedom of expression uses the doctrine of the "Clear and Present Danger" test at both levels of legislation and constitutional practice. The Law of Georgia on Freedom of Speech and Expression provides for the use of the "Clear and Present Danger" test in assessing the "call" itself. According to Article 4 of the law, "a call shall give rise to liability established by law only when a person commits an intentional act which creates a clear, direct and substantial threat of an unlawful result" 24 . The "Clear and Present Danger" test is provided by the Law of Georgia on Assemblies and Demonstrations. Article 11 of the law stipulates that "during the planning and holding of a rally or demonstration, a call for the overthrow or violent change of the constitutional order of Georgia, violation of the country's independence and territorial integrity, or a call for propaganda of war and violence; stirring national, religious or social strife, and posing a clear, direct and substantial threat to the activities found in this paragraph" 25 .

The doctrine of "clear and present danger" was developed by the Constitutional Court of Georgia in its decision of 18 April 2011, explaining that the call for violence must pose a real threat, "an obvious, direct and substantial threat of an unlawful outcome" ${ }^{26}$. The Constitutional Court of Georgia points to a neutral Georgian model in

\footnotetext{
${ }^{20}$ Case Law in the United States and Europe, Chapter II, Liberty Institute, 2005, p. 80.

${ }^{21}$ Law of Georgia on Assemblies and Demonstrations, June 12, 1997.

${ }^{22}$ A thesis by Eva Gotsiridze on "Freedom of Expression in the Context of a Fair Balance of Conflicting Values (in accordance with the jurisprudence of the European Convention on Human Rights and the Strasbourg Court)", International Law Institute - TSU, 2007, pp. 407-408.

${ }^{23}$ A thesis by Eva Gotsiridze on "Freedom of Expression in the Context of a Fair Balance of Conflicting Values (in accordance with the jurisprudence of the European Convention on Human Rights and the Strasbourg Court)", International Law Institute - TSU, 2007, p. 405.

${ }^{24}$ Law of Georgia on Freedom of Speech and Expression. June 24, 2004.

${ }^{25}$ Law of Georgia on Assemblies and Demonstrations, June 12, 1997.

${ }^{26}$ A ruling by the Constitutional Court of Georgia on the Case №2/482,483,487,502 "Political Union of the Citizens Movement for United Georgia", "Political Union of the Citizens Georgian Conservative Party", Citizens of Georgia Zviad Dzidziguri and Kakha Kukava, Georgian Young Lawyers Association, Citizens Dachi Tsaguria and Jaba Jishkari, "Public Defender of Georgia v. Parliament of Georgia", April 18, 2011, Article II.105; EMC criticism of Ioseb Jachvliani's Legislative Initiative for Insulting Religious Feelings, 2016, https://socialjustice.org.ge/ka/products/emc-s-kritika-religiuri-grdznobebis-sheuratskhqofis-sakitkhze-ioseb-jachvlianissakanonmdeblo-initsiativaze [L.s. 24.09.2021]
} 
terms of freedom of expression in the case of Giorgi Kipiani and Avtandil Ungiadze. According to the court, "the inadmissibility of position, values, and ideas cannot be a ground for restricting freedom of expression. The state is obliged to protect objectively identifiable interests and not the subjective feelings" 27 .

\section{The scope of the court's criticism under the First Amendment to the U.S. Constitution}

The U.S. model of freedom of expression defends criticism of the court and the individual judge to a high degree and ranks it as a protector of political expression ${ }^{28}$. According to the U.S. model of freedom of expression, judges are integrated into the notion of a "public figure" and have a duty to listen to criticism. On the case Syllabus: New York Times Co. V. Sullivan, The Supreme Court of the United States ruled that criminal liability for criticizing a judge to protect the authority and reputation of a court could not be justified unless there was an obvious and immediate threat to the proper administration of justice ${ }^{29}$.

The U.S. Supreme Court stated on the Landmark Communications case that "law does not provide judges with greater immunity from criticism than other individuals and institutions. The activities of the courts and the legal conduct of judges are an important area of public interest" ${ }^{30}$.

The first decision by the U.S. Supreme Court to be criticized was the case McCulloch v. Maryland ${ }^{31}$ of 1819 . In the ruling, the Supreme Court clarified that it was the U.S. Congress that was empowered to set up the national banking system. This decision of the Supreme Court faced wide criticism. According to former U.S. President Thomas Jefferson, the court was a "corps of unsuspecting miners and sappers" who "continually worked undercover to overthrow the Confederate enterprise" ${ }^{32}$.

The Supreme Court of the United States uses the "Brandenburg Three-Element Test" to restrict freedom of expression on the grounds of contempt of court. Restricting freedom of expression through the practice of the U.S. Supreme Court requires a clear and real threat to the independence of the judiciary and the proper administration of justice ${ }^{33}$.

The U.S. model of freedom of expression involves the protection of the freedom of the press of the highest standard, due to its special role in society.

Under the U.S. model of freedom of expression, imposing a sanction on the press is unacceptable for contempt of court unless there is a "clear and present danger" to the administration of justice ${ }^{34}$.

On the case of Bridge v. California, the Supreme Court ruled that a restriction of freedom of expression in the media due to contempt of court should be assessed using the "Clear and Present Danger" test, when the proper administration of justice is in "clear and present danger"35. According to the standard developed in the Bridges case, the First Amendment to the U.S. Constitution protects insulting expressions against the judiciary and the judge, and sharp criticism of court decisions.

\footnotetext{
${ }^{27}$ A ruling by the Constitutional Court of Georgia on the Case №1/3/ 421,422 "Citizens of Georgia Giorgi Kipiani and Avtandil Ungiadze v. Parliament of Georgia", November 10, 2009. Article II.7.

${ }^{28}$ Case Law in the United States and Europe, Chapter II, Liberty Institute, 2005, p. 23.

${ }^{29}$ A ruling by the Supreme Court of the United States on the Case of "New York Times v. Sullivan", 1963.

${ }^{30}$ A ruling by the Supreme Court of the United States on the Case No. 435 U.S. 829 Landmark Communications v. Virginia, 1978. Also, G. Tsulukidze, R. Kakabadze, V. Berekashvili, "Freedom of Expression and Protection of Judicial Independence and Impartiality", Georgian Democratic Initiative (GDI), 2020, 55.

${ }^{31}$ A ruling by the Supreme Court of the United States on the Case No. 316316 "McCulloch v. Maryland", 1819.

${ }^{32}$ G. Tsulukidze, R. Kakabadze, V. Berekashvili, "Freedom of Expression and Protection of Judicial Independence and Impartiality", Georgian Democratic Initiative (GDI), 2020, p. 45.

${ }^{33}$ A ruling by the Supreme Court of the United States on the Case No. 376 U.S. 254 "New York Times v. Sullivan", 1963.

${ }^{34}$ Article 19" Background Paper on Freedom of Expression and Contempt of Court, International Seminar on Promoting Freedom of Expression With the Three Specialised International Mandates. 29-30 November, 2000 p.8.

${ }^{35}$ A ruling by the Supreme Court of the United States on the Case No. 314 US 252 "Bridge v. California”, 1941.
} 
The U.S. Supreme Court used the "Clear and Present Danger" test in assessing restrictions on freedom of expression through the case of Pennekamp v. Florida ${ }^{36}$. In the case cited, newspaper publishers criticized the court, saying the court rulings served the interests of criminal authorities and were beneficial to the gambling business.

The publishers of the newspaper were accused of violating the authority of the court holding such opinions. According to the Supreme Court in the case, the judiciary must be receptive to expressions that are critical and offensive to them, and that "weak individuals cannot be judges" ${ }^{37}$. According to the Supreme Court, when restricting freedom of expression, the content of the expression and the circumstances in which the expression took place must be taken into account.

In the case of Craig v. Harney, the Supreme Court clarified that "the law regulating harassment cannot be a refuge for judges, who are sensitive to the fierce public criticism"38.

According to the U.S. model, restricting freedom of expression on the basis of ensuring the independence of the judiciary requires the fulfillment of two preconditions: posing a threat to the proper administration of justice and speaking out against the ongoing case and its judge ${ }^{39}$.In order to restrict freedom of expression, it is important that "the malicious intent actually inflicted be extremely serious and that the likelihood of danger be high" ${ }^{40}$. The high standard of protection of freedom of expression in the United States is manifested in the fact that it is virtually impossible to access the content of expression, and basically, the restriction of freedom of expression can only apply to the form, time and place of expression. The U.S. model offers a substantively neutral regulation of restrictions on freedom of expression, indicating its high standard of protection. According to the manner developed by the U.S. Supreme Court regarding the First Amendment to the Constitution, restrictions on freedom of expression are almost impossible due to public insults and criticism $^{41}$.

U.S. federal court judges enjoy high protection guarantees. They are appointed on a permanent basis. The impeachment procedure against them is carried out in exceptional cases. The impeachment process requires the consent of both houses of Congress. Under conditions of high guarantees of independence, federal judges exercise strict judicial control over the exertion of the principle of separation of powers under the U.S. Constitution during their judicial terms, even if their decisions are met with harsh public criticism. ${ }^{42}$

Unlike the U.S. model of freedom of expression, Article 10 of the European Convention on Human Rights names a broadly interpreted basis for restricting freedom of expression - the authority of the judiciary and its protection due to its special role, status and public interest ${ }^{43}$ as well as emphasizing the importance of maintaining trust in the judiciary throughout a democratic society ${ }^{44}$. The European Court of Human Rights narrowly defines the scope of admissible criticism of the court in contrast to the U.S. model, citing the judge's inability to respond to public criticism ${ }^{45}$. The European Court of Justice has ruled in the Prager and Oberschlick case that "the special role of the judiciary in society must be taken into account. As a guarantor of justice, the judiciary must enjoy the public trust in order to successfully carry out its duties. In this way, it

\footnotetext{
${ }^{36}$ A ruling by the Supreme Court of the United States on the Case No. 328 U.S. 331 Pennekamp v. Florida, 1946.

${ }^{37}$ Freedom of Expression in Georgia, GDI, 2020, 29.

${ }^{38}$ A ruling by the Supreme Court of the United States on case No. 331 US 367 "Craig v. Harn", 1947.

${ }^{39}$ A ruling by United States on case No. 314 US 252 "Bridge v. California", 1941. Decision by the Supreme Court of the United States on case no. 328 U.S. 331 "Penenkamp v. Florida", 1946. Decision by the Supreme Court of the United States on case No. 331 US 367 "Craig v. Harn", 1947. Decision by the Supreme Court of the United States om case No. 370 US 375, 1962.

${ }^{40}$ Background Paper on Freedom of Expression and Contempt of Court, for the International Seminar on Promoting Freedom of Expression. 29-30 November 2000, p.8.

${ }^{41}$ G. Beraia, The Problem of Restriction of Freedom of Expression in the Name of Protecting the Authority of the Judiciary: Theory and Practice of National Courts, European Court of Human Rights, Supreme Court of the United States, and UN Human Rights Committee, Review of Constitutional Law, XI, 2017, p.62.

${ }^{42}$ Hon. Marilyn L. Huff, The Effects of Public Criticism of the Judiciary on Judicial Independence, U.S. Federal Judges Association, 2018, p.2. https://www.federaljudgesassoc.org/egov/documents/1539117619_2837.pdf [1.s.24.09.2021].

${ }^{43}$ A ruling by the European Court of Human Rights on Case No. 51160/06 "Di Giovanni v. Italy", 9 July 2013. Paragraph 71.

${ }^{44}$ A ruling by the European Court of Human Rights on Case No. 73797/01 Kyprianou v. Cyprus, 15 December 2005. Paragraph 172.

${ }^{45}$ A ruling by the European Court of Human Rights on Case No. 29492/05 "Kudeshkina v. Russia", 26 February 2009. Paragraph 86.
} 
may find it necessary to protect such confidence from unfounded and destructive attacks, especially in view of the fact that judges, who are criticized for their professional status, are prohibited from responding to such criticism" ${ }^{46}$. The "legitimate aim of ensuring judicial authority", under Article 10-22 of the European Convention on Human Rights, makes it possible to include freedom of expression in the context of the general, abstract and subjectively interpretable notion of "judicial authority". A substantial shift in the practice of the European Court of Human Rights in favor of freedom of expression took place in 2015, when the European Court of Human Rights ruled in two cases: Morice v. France and Peruzzi v. Italy. According to the European Court of Human Rights, the court, as a public institution, has a greater obligation to listen and "in the process of carrying out its activities, it may be subject to wider criticism than ordinary citizens". ${ }^{47}$ The case of Marian Maciejewski v. Poland was about a journalist producing a critical article about people working in the justice system titled "Thieves in the Justice System". The journalist referred to those employed in the justice system as "mafia-like" judges and prosecutors. The journalist was fined for defamation. On this very case, the European Court of Human Rights found a violation of Article 10 of the Convention ${ }^{48}$. In this case, the European Court of Human Rights had ruled that it would assess the interference with the freedom of expression of the media with a rigorous test in cases, where a specific sanction would prevent media outlets from covering debates of high public interest. There is a high public interest in the ongoing processes and shortcomings in the judiciary, and the media in this case has a crucial role to play in verifying whether the actions of judges are in line with the principle of good faith ${ }^{49}$.

\section{The "Sub Judice"50 Rule and the "Contempt of the Court" Doctrine ${ }^{51}$}

The rule of restricting comment on the case under consideration stems from the English Doctrine of "Contempt of the Court" 52 , which the U.S. model of freedom of expression is based on ${ }^{53}$. The "Contempt of the Court" doctrine prohibits the dissemination of information about the case under discussion in order to prevent pretrial and pre-trial adjudication, public pressure on the court or parties, which may lead to human rights violations to a fair and impartial tribunal, as well as the violation of the procedural rights of the accused in criminal cases $^{54}$.

The U.S. model of freedom of expression is characterized by restrictions on freedom of expression in commenting on ongoing cases in court, which is "explained by the media's role in the prevention of parallel justice". ${ }^{55}$ In commenting on ongoing cases, possible restrictions on freedom of expression are based on the view that no one should interfere in the actual court proceedings, restricting or questioning the right to a fair trial $^{56}$.

\footnotetext{
${ }^{46}$ A ruling by the European Court of Human Rights on Case No. 15974/90 "Prager and Oberschlick v. Austria", 26 April 1995. Paragraph 34

${ }^{47}$ A ruling by the European Court of Human Rights on Case no. 29369/10 "Moroce v. France", 23 April 2015. Decision by the European Court of Human Rights on Case No. 39294/09 "Peruzzi v. Italy", 30 June 2015.

${ }^{48}$ A ruling by the European Court of Human Rights on case No. 34447/05 "Marian Maciejewski v. Poland", judgment of January 13, 2015.

${ }^{49}$ Ibid.

${ }^{50}$ The term "Sub Judice" translates as "the Case is under Consideration".

${ }^{51}$ A common doctrine of common law countries, according to which, the courts have the power to impose legal liability on those who attempt to interfere with justice.

${ }^{52}$ Contempt of the Court.

${ }^{53}$ Background Paper on Freedom of Expression and Contempt of Court, for the International Seminar on Promoting Freedom of Expression. 29-30 November 2000, p.1.

54 E. Gotsiridze, Restriction of Freedom of Expression to Protect the Authority and Impartiality of the Court (Review of the Jurisprudence of the Strasbourg Court) Law and the World, N13, 2019, 44.

${ }_{55}$ Article 19 "Background Paper on Freedom of Expression and Contempt of Court" 2000 p.5.

${ }^{56} \mathrm{G}$. Beraia, The Problem of Restriction of Freedom of Expression in the Name of Protecting the Authority of the Judiciary: Theory and Practice of National Courts, European Court of Human Rights, Supreme Court of the United States, and UN Human Rights Committee, Review of Constitutional Law, XI, 2017, p. 67.
} 
On the case of Attorney-General v Times Newspapers Ltd ${ }^{57}$, the English Court explained that "the right to a fair trial primarily means the unrestricted right of all citizens to apply to the court to assert their rights and duties. At the same time, this right also implies that citizens have a sense that the court is protected from all forms of bias and that decisions are made only on the basis of the arguments and evidence presented. The third component also implies that once the case has been accepted by the court, there is no other body and person capable of usurping the power of the court. Any action that violates the previous criteria will be considered an insult to the court" ${ }^{\prime 5}$. By the standard developed in the Attorney-General v Times Newspapers Ltd case, the core of the contempt of the court doctrine is to prevent the substantial risk of pre-trial review and pre-trial evaluation ${ }^{59}$. With proper court administration, the scope of protection of this doctrine is to protect witnesses from victimization and damaging criticism of the court in the press ${ }^{60}$.

The U.S. Code of Judicial Ethics prohibits judges from making public comments on the substantive issues of a case under consideration or in waiting. ${ }^{61}$

In contrast to the U.S. model, the European Court of Human Rights sets a relatively low standard of protection of freedom of expression when commenting on a case under consideration. According to the case law of the European Court of Human Rights, in assessing the impact of a publication on the administration of justice in the ongoing case, the European Court takes into account at the time of publication, the content (the extent of provocativeness) and the status of the trial judge ${ }^{62}$. In determining the temporal aspect of publication, the European Court takes into account the critical timing of releasing publication, and commenting on the trial in order to uphold the presumption of innocence. ${ }^{63}$ The European Court also takes into account the peculiarities of the trial and adjudication by the jury, the non-professional status of jurors and the possible influence of commentary on the administration of justice. ${ }^{64}$ According to the standard of the European Convention on Human Rights, if jurors are influenced by a preconceived notion about a case, then the chances of a fair trial are greatly diminished ${ }^{65}$. In the case of Seckerson and Times Newspapers Limited $v$. UK ${ }^{66}$, the head juror and the Times newspaper were found guilty of contempt of court and fined for revealing the secrets of the jury meeting, which was revealed in a Times article published, where the head juror expressed his concerns about the trial in which he was involved. The European Court of Human Rights has clarified that the rules that oblige the jury to maintain the confidentiality of the jury are important for ensuring the authority and impartiality of the court ${ }^{67}$.

The European Court of Human Rights in the case of Worm v. Austria ${ }^{68}$ clarified that "journalists should always remember to refrain from making statements that could call into question the will of an individual, whether intentionally or unintentionally, in a fair trial or in the public confidence in the role of the courts in a democratic society". 69

\footnotetext{
${ }^{57}$ Attorney-General v Times Newspapers Ltd: HL 1973.

${ }^{58}$ G. Beraia, The Problem of Restriction of Freedom of Expression in the Name of Protecting the Authority of the Judiciary: Theory and Practice of National Courts, European Court of Human Rights, Supreme Court of the United States, and UN Human Rights Committee, Review of Constitutional Law, XI, 2017, pp. 67-68.

${ }^{59}$ E. Gotsiridze, Restriction of Freedom of Expression to Protect the Authority and Impartiality of the Court (Review of the Jurisprudence of the Strasbourg Court) Law and the World, N13, 2019, 44.

${ }^{60}$ Consultant Editor C.J. Miller and David Perry QC, Miller on Contempt of Court, fourth edition, 2018, 2-7.

${ }^{61}$ Code of Conduct for United States Judges Canon 3 (A) (6).

${ }^{62}$ Guide on Article 10 of the European Convention on Human Rights, Freedom of expression Updated - 31 August 2020, 82.

${ }^{63}$ A ruling by the European Court of Human Rights on Case No. 17107/05 "Campos Damaso v. Portugal", 24 April 2008. Paragraph 35.

${ }^{64}$ A ruling by the European Court of Human Rights on Case No. 53886/00 Turanshaw and Julie v. France, 24 November 2005. Paragraph 75.

${ }^{65}$ E. Gotsiridze, Restriction of Freedom of Expression to Protect the Authority and Impartiality of the Court (Review of the Jurisprudence of the Strasbourg Court) Law and the World, N13, 2019, 44.

${ }^{66} \mathrm{https}$ ://ukhumanrightsblog.com/2012/02/08/times-contempt-challenge-thrown-out-in-strasbourg/ [1.s.24.09.2021].

${ }^{67}$ F. Leach, Taking a Case to the European Court of Human Rights, Fourth Edition, Student Version, 2017, 490.

${ }^{68}$ A ruling by the European Court of Human Rights on Case No.22714 / 93 "Worm v. Austria”, 29 August 1997. Paragraph 50.

${ }^{69}$ E. Gotsiridze, Restriction of Freedom of Expression to Protect the Authority and Impartiality of the Court (Review of the Jurisprudence of the Strasbourg Court) Law and the World, N13, 2019, 46.
} 


\section{The extent of lawyers' freedom of expression in relation to criticism of the justice system}

In terms of freedom of expression for lawyers, the U.S. Supreme Court largely shares a similar standard to that of the European Court of Human Rights. The U.S. Supreme Court takes a tough approach to the scope of a lawyer's freedom of expression, given the important role a lawyer plays in administering justice. According to the U.S. Supreme Court standard, attorneys should refrain from criticizing the judiciary not to undermine public confidence in the justice system. According to the U.S. Supreme Court, a lawyer's freedom of expression is restricted in the face of judicial criticism if it threatens the proper administration of justice. In the In re Sawyer case, attorney Sawyer described the trial as "dangerous and shocking", and criticized the ongoing court hearings. In keeping with the U.S. Supreme Court, a lawyer has the right to criticize state law. Sawyer criticized the court hearings, however, while criticizing; he focused on the problem of legislation and did not mention the name of the judge hearing the case. According to the standard developed in the Sawyer case, a lawyer should not be criticized for violating the country's flawed legislation or professional ethics, unless the lawyer's statement "does not endanger the proper administration of justice" ${ }^{\text {"70 }}$. Later, the U.S. Supreme Court in the case of Gentile v. The State Bar of Nevada developed a standard of freedom of expression for lawyers and emphasized the doctrine of "real harm" posed either to the right or interest" ${ }^{71}$. The U.S. Supreme Court in the case of Sacher v. The United States, justified the imposition of contempt of the court on five attorneys, who attempted to interfere with justice and obstruct the trial ${ }^{72}$.

Accordingly, under the U.S. Standard on Freedom of Expression, professional and ethical discipline of attorneys may be exercised if they threaten the smooth administration of justice and the administration of the judiciary ${ }^{73}$.

The standard of the European Court of Human Rights on the freedom of expression of the lawyer is based on an understanding of the special status and central role of the lawyer in the proper administration of justice, acting as a mediator between the public and the court. It is lawyers who play a crucial role in ensuring that public confidence in the courts is maintained ${ }^{74}$. In obedience to the standard of the European Court of Human Rights, within the framework of freedom of expression, a lawyer cannot be equated with a journalist due to their different role in the judicial process. Journalists have the right, as part of their official activities, to disseminate and express ideas on any matter of public interest, including issues related to the administration of justice. Lawyers, on the other hand, are supporters of the justice system, direct participants in ensuring its enforcement and upholding the interests of their clients ${ }^{75}$.

The standard of the European Court of Human Rights should not be perceived in such a way that lawyers are generally deprived of the opportunity to exercise their freedom of expression. They have the right to comment on trials and justice issues. It is simply that their expression is to some extent within the framework of a lawyer's professional ethics, which is due to their special role in the justice process.

The European Court of Human Rights in the case of Schöpfer v. Switzerland clarified that lawyers have the right to comment on the judicial process; however, their expression should not contain language that is detrimental to the authority of the court ${ }^{76}$.

According to the standard developed in the case of Morice v. France, "lawyers enjoy freedom of expression. This includes not only the essence of ideas and information, but also the form of their expression. Lawyers

\footnotetext{
${ }^{70}$ A ruling by the Supreme Court of the United States on the Case No. 124 U.S. 200 In Re Sawyer, June 29, 1959. on the Case of In re Sawyer.

${ }^{71}$ A ruling by the Supreme Court of the United States on the Case No. 501 U.S. 1030 Gentile v. Nevada, 27 June 1991.

${ }^{72}$ A ruling by the Supreme Court of the United States on the Case No. 343 U.S. 1 Sacher v. United States, 10 March 1952.

73 The Connecticut Court of Appeal on the Case No. 17341. Notopoulos v. Statwaid Grevens, 24 September 2003.

${ }^{74}$ A ruling by the European Court of Human Rights on the Case No. 29369/10 „, Morice v. France, 23 August 2015. Paragraphs 132139; Decision by the European Court of Human Rights on the Case No. 31611/96 "Nicola v. Finland”, 21 March 2002. Paragraph 45.

${ }^{75}$ Guide on Article 10 of the European Convention on Human Rights, Freedom of expression, Updated - 31 August 2020; p.78.

${ }^{76}$ A ruling by the European Court of Human Rights on the Case No.25405 / 94 "Driver v. Switzerland", 20 May 1998.
} 
have the right to express their views publicly on the administration of justice, provided that criticism does not go beyond certain limits and that justice is protected from unwarranted attacks and that it is motivated only by a desire or strategy to have a debate on justice in the media. Lawyers' statements should be considered and evaluated in a general context, considering the extent to which lawyer' criticism of justice can be seen as a misleading or unjustified personal assault. It should also be checked whether their statements are related to the factual circumstances of the case". ${ }^{77}$

The 2018 decision of the European Court of Human Rights on the case of Ottan v. France was quite revolutionary, since France was found to be the violator of the freedom of expression of the lawyer. The case was about the lawyer's statement to the jury after the trial that the jurors who heard the case were all white and did not represent all groups in society. Accordingly, a verdict of acquittal was expected. ${ }^{78}$ The lawyer was given a disciplinary sanction as a warning, since the French national courts found the lawyer's assessment to be made on racial grounds. The European Court did not share the national court's assessment of the lawyer's statement to be based on racial grounds, explaining that "the author's position could be counted as a widely held view that the impartiality of judges, whether professional or jurors, is a value that does not exist in abstract; rather, it is the result of significant efforts to eradicate even unconscious bias, which, in a particular case, may be geographical or social, and which may further instill in people a fear that they will be misunderstood". ${ }^{79}$

It follows from the rulings of the European Court of Human Rights that criticism of the court by a lawyer is not always inadmissible and should be assessed on the basis of cumulative factors.

\section{Case law of the Constitutional Court of Georgia and common courts}

In the area of restriction of freedom of expression on the basis of judicial independence and impartiality, the standard of the Constitutional Court of Georgia considers the legitimate aim of restricting freedom of expression to be only the administration of successful, prompt and effective justice and the maintenance of order in the court ${ }^{80}$. The Georgian model of freedom of expression is influenced by the U.S. model.

According to the standard of the Constitutional Court of Georgia, expressing an opinion regarding the activities of a judge is considered a constitutional right ${ }^{81}$. According to the Constitutional Court, "expressing an opinion on the activities of a judge is a constitutional right. As a public figure, a judge has indeed an obligation to listen, insofar as criticism of his/her works as well as discussion of his/her professional or personal qualities may be in the public interest" ${ }^{92}$. According to the court, overseeing the independence of the judge does not mean banning the professional activity of the judge or criticizing the court decision. "It is a constitutional human right to express one's attitude towards the work of the court, including through gatherings (demonstrations) in the vicinity of the court" ${ }^{\prime \prime 3}$.

The standard of the Supreme Court of Georgia shares the approach of the European Court of Human Rights to restricting the Freedom of Expression on the grounds of being disrespectful to court.

\footnotetext{
${ }^{77}$ A ruling by the European Court of Human Rights on the Case No. 29369/10 "Morice v. France", 23 April 2015. Paragraphs 132139.

${ }^{78}$ G. Tsulukidze, R. Kakabadze, V. Berekashvili, Freedom of Expression and Protection of Judicial Independence and Impartiality, Georgian Democratic Initiative (GDI), 2020, pp.57-58.

${ }^{79}$ Ibid.

${ }^{80}$ A ruling by the Constitutional Court of Georgia on the Case №1/3/393,397 “Citizens of Georgia Vakhtang Masurashvili and Onise Mebonia v. Parliament of Georgia", 15 December 2006.

${ }^{81}$ A ruling by the Constitutional Court of Georgia on the Case №2/482,483,487,502 Citizens' Political Union “Movement for United Georgia", Citizens' Political Union "Conservative Party of Georgia", Citizens of Georgia Zviad Dzidziguri and Kakha Kukava, Georgian Young Lawyers Association, Citizens Dachi Tsaguria and Jaba Jishkhar Defender v. Parliament of Georgia “, 18 April 2011. Paragraph 67.

${ }^{82}$ Ibid.

${ }^{83}$ Ibid. Paragraph 66
} 
The Supreme Court of Georgia ruled ${ }^{84}$ on April 16, 2019, that a critical expression of a judge by businessman Fadi Asli was a protected right to freedom of expression on a judge's corruption. The Supreme Court in its decision underlined the ongoing judicial reform in the country, its high public importance and the need for a public debate on the judicial system. According to the Supreme Court, "In a situation where the country is undergoing judicial reform and the judiciary is top in the public interest, restrictions on freedom of expression will be allowed only in the case of an exceptional, overt and negative attack on the judiciary/judge, aiming to weaken the role of the judiciary, to undermine the independence of the judiciary, and only the above should be the objective of the disseminator. Otherwise, interference with the freedom of expression by the state authority may harm the interests of the country, making it impossible for the public to express an opinion on the progress of the reform, which, naturally, negatively affects the interests of the country and the administration of effective justice. According to the case law, issues related to the functioning of the judiciary, which are an extremely important institution for a democratic society, are in the public interest. In this regard, it is necessary to consider the special role of the court in society" ${ }^{\prime \prime 5}$.

In its judgement of 16 April 2019, the Supreme Court drew a line between a statement made in a courtroom and a statement made outside the courtroom. According to the Supreme Court, "regarding the authority of the court, as well as the rights of individual judges, it should be noted that certain regulations have been established by the legislation of Georgia in order to take preventive measures to avoid danger. When misconduct or certain statements are made in a courtroom, procedural law (see, for example, Articles 211 and 212 of the CCOG) establishes the rule of liability for the offender and the possibility of imposing the relevant sanction. In order to avoid the negative consequences of information disseminated outside the courtroom, the person, against whom the information was disseminated, has the right under Article 1844 of the Civil Code to publish retaliatory information in the same mass media, disseminating the statement" ${ }^{\prime 26}$.

\section{Article 366 of the Criminal Code of Georgia and its compliance with international standards}

Article 366 of the Criminal Code of Georgia (contempt of court) is incompatible with international standards for the protection of freedom of expression.

According to the first part of Article 366 of the Criminal Code of Georgia, insulting a participant in a lawsuit is considered disrespectful to the court. According to the second part of the same article, insulting a court is the same as insulting a member of a Constitutional Court, a judge or a juror ${ }^{87}$.Due to the ambiguity and unpredictability of the norm, any expression that is perceived as disrespectful to the court can be considered as an offensive act, for which Article 366 provides for criminal liability.

Article 366 of the Criminal Code does not define what is meant by "contempt of court" and "insult to the court", which allows for a vague and arbitrary interpretation of the norm. The U.S. Supreme Court in the case of Roth v. The US clarified that, "the law should issue a clear warning about what action is prohibited by law. The predictability of a language is assessed by everyone through the understanding of its content and its fulfilment in practice" 88 .

The vagueness ${ }^{89}$ of the Article 366 of the Criminal Code makes it difficult for an individual to distinguish between a constitutionally protected and an inadmissible expression. The ambiguity and unpredictability of Article 366 of the Criminal Code is also reflected in the fact that Article 366 of the Criminal Code allows for such a wide interpretation that it prohibits the essential part of freedom of expression protected by Article 17

\footnotetext{
${ }^{84}$ A ruling by the Supreme Court of Georgia on the Case No. AS-591-591-2018 “Vladimer Kajabadze vs. Fadi Asli”, April 16, 2019. ${ }^{85}$ Ibid.

${ }^{86}$ A ruling by the Supreme Court of Georgia on the Case NAS-591-591-2018 “Vladimer Kajabadze v. Fadi Asli”, April 16, 2019.

${ }^{87}$ Article 366 of the Criminal Code of Georgia, https://matsne.gov.ge/ka/document/view/16426?publication=235 [1.s.24.09.2021].

${ }^{88}$ A ruling by the Supreme Court of the United States on the Case No. 354 U.S. 476 Roth v. United States. 1957.

${ }^{89}$ The vagueness of the law related to freedom of expression involves that it is difficult for a person to distinguish between legally permissible and impermissible expression due to an ambiguous and unpredictable norm.
} 
of the Constitution of Georgia (overbreadth doctrine) ${ }^{90}$. The U.S. Supreme Court on the case of Bagett v. Bullitt ruled that with an unpredictable and indefinite norm, a person also moves away from the area where freedom of expression is constitutionally protected and tries to refrain from expressing an area where an unforeseen prohibition under the law can operate ${ }^{91}$. Article 366 of the Criminal Code, due to its ambiguity, does not allow for a uniform reading of the norm, thus violating the constitutional principle of definiteness ${ }^{92}$.

The ambiguity of Article 366 of the Criminal Code makes it possible to extend the scope of restrictions on freedom of expression so much that the government is given carte blanche to restrict only content that is politically or otherwise unacceptable to it. The vague wording of Article 366 of the Criminal Code does not allow "ordinary people to understand what the state forbids them to do" $"$. The unpredictability of Article 366 of the Criminal Code "poses a threat to the court to rewrite a vague rule of law and set a standard of its own, which may not have been the aim of the legislature" fate of the accused depends on the discretion and whims of the judge" $"$, as was revealed in the case of Zviad Kuprava, found guilty of contempt of court by the judge, manifested in insulting the judge ${ }^{96}$. According to the Constitutional Court of Georgia, "the decision to declare an action punishable is the exclusive authority of the legislator. Accordingly, he/she must use this power in such a way that the offender is not allowed, on the basis of judicial practice, to form the composition of a criminal act" $"$.

Such vague norms bear a "deterrent effect", forcing the public to refrain from critical expression in debates that contribute to public debate for fear of sanctions, and to limit themselves to the part of expression that is a constitutionally protected benefit. Under the conditions of the "deterrent effect", the society resorts to selfcensorship and refrains from expressing it for fear of disproportionate sanctions ${ }^{98}$.

\section{Conclusion}

Although freedom of expression is not an absolute right and can be restricted, in order to protect the authority of the court, by both international and Georgian standards, "making speech fall victim to justice" is inadmissible. The Georgian constitutional model of freedom of expression is influenced by the United States and protects the right to criticizing a judge to a high degree. Similar to the U.S. model, the Georgian model of freedom of expression is based on a primitive neutral restriction on freedom of expression, which indicates a high standard of protection of freedom of expression. The Georgian constitutional standard for restricting freedom of expression, in order to conduct the process of justice smoothly, properly, and effectively, is legitimately affected by the "Clear and Present Danger Test" in the Brandenburg case and shares the U.S. standard of freedom of expression. In the part of the court criticism, the Georgian model develops a contentneutral regulation and prevents the restriction of the subject of expression.

\footnotetext{
${ }^{90}$ Overbreadth doctrine: this doctrine is typical of the U.S. model of freedom of expression and implies that the norm on freedom of expression is interpreted so broadly that it prohibits both protected and inadmissible expression under the First Amendment to the Constitution.

${ }^{91}$ A ruling by the Supreme Court of the United States on the Case No. 377 U.S. 360 "Bagett v. Bullitt", 1964.

92 A ruling by the Constitutional Court of Georgia on the Case №1/1/657 "Citizen of Georgia Giorgi Putkaradze v. Parliament of Georgia", June 2, 2017 Paragraph 15.

${ }^{93}$ A ruling by the Supreme Court of the United States on the Case No. "Kolender v. Lawson". 1983.

${ }^{94}$ A ruling by the Supreme Court of the United States on the Case No. 383 U.S. 463 Ginzburg v. United States 1965.

${ }^{95}$ Ibid.

${ }^{96}$ Freedom of Expression, GDI, 2020, p. 26-29.

${ }^{97}$ A ruling by the Constitutional Court of Georgia on the Case №2/2/516 "Citizens of Georgia; Alexandre Baramidze, Lasha Tugushi, Vakhtang Khmaladze and Vakhtang Maisaia v. Parliament of Georgia", 14 May 2014. Paragraph 37.

98 A ruling by the European Court of Human Rights on the Case No. 33629/06 Vajnai v. Hungary, 8 October 2008. Paragraph 54. Decision by the European Court of Human Rights on the Case No. 33348/96 Cumpana and Mazare v. Romania, 17 December 2004. Paragraph 114
} 


\section{BIBLIOGRAPHY}

1. A ruling by the Constitutional Court of Georgia: Political Union of the Citizens "Movement for United Georgia", Political Union of the Citizens "Georgian Conservative Party", Georgian Citizens Zviad Dzidziguri and Kakha Kukava, Georgian Young Lawyers Association, Citizens Dachi Tsaguria and Jaba Jishkariani, Public Defender of Georgia V. Parliament", 18.04.2011; https://matsne.gov.ge/ka/document/view/1309814?publication=0 [last seen 30.09.2021];

2. A ruling by the Constitutional Court of Georgia: "Citizens of Georgia Giorgi Kipiani and Avtandil Ungiadze v. Parliament of Georgia”, 10.11.2009; https://constcourt.ge/ka/judicial-acts?legal=300 [last seen 30.09.2021];

3. A ruling by the Constitutional Court of Georgia: "Citizens of Georgia Vakhtang Masurashvili and Onise Mebonia v. Parliament of Georgia”, 15.12.2006; https://constcourt.ge/ka/judicial-acts?legal=310 [last seen 22.09.2021];

4. A ruling by the Supreme Court of Georgia: "Vladimer Kadjabadze v. Fadi Asli", 16.04. 2019;

5. A ruling by the Constitutional Court of Georgia: "Citizen of Georgia Giorgi Putkaradze v. Parliament of Georgia", June 2, 2017; https://constcourt.ge/ka/judicial-acts?legal=899 [last seen 22.09.2021];

6. A ruling by the Constitutional Court of Georgia: "Citizens of Georgia: Alexander Baramidze, Lasha Tugushi, Vakhtang Khmaladze and Vakhtang Maisaia v. Parliament of Georgia", 14.05.2014; https://matsne.gov.ge/ka/document/view/1925761?publication=0 [last seen 15.09.2021];

7. A ruling by the Supreme Court of the United States of America: "Schenck v. United States of America", March 3, 1919; https://www.oyez.org/cases/1900-1940/249us47 [last seen 15.09.2021];

8. A ruling by the Supreme Court of the United States of America: "Brandenburg v. Ohio", June 9, 1969; https://www.oyez.org/cases/1968/492 [last seen 24. 09.2021];

9. A ruling by the Supreme Court of the United States of America: “Abrams v. United States of America”, 10.11.1919; https://www.oyez.org/cases/1900-1940/250us616 [last seen 15.09.2021];

10. A ruling by the Supreme Court of the United States of America: "Gitlow v. New York", June 8, 1925; https://www.oyez.org/cases/1900-1940/268us652 [last seen 3.10.2021];

11. A ruling by the Supreme Court of the United States of America: "New York Times v. Sullivan”, March 9, 1963; https://www.oyez.org/cases/1963/39 [last seen 3.10.2021];

12. A ruling by the Supreme Court of the United States of America: "Landmark Communications v. Virginia", 1.05.1978; https://supreme.justia.com/cases/federal/us/435/829/ [last seen 3.10.2021];

13. A ruling by the Supreme Court of the United States of America: "Mcculloch v. Maryland", 6.03.1819; https://www.oyez.org/cases/1789-1850/17us316 [last seen 3.10.2021];

14. A ruling by the Supreme Court of the United States: "Bridges v. California", 8.12.1941; https://www.oyez.org/cases/1940-1955/314us252 [last seen 16.10.2021];

15. A ruling by the Supreme Court of the United States of America: "Pennekamp v. Florida", 3.06.1946; https://supreme.justia.com/cases/federal/us/328/331/ [last seen 16.10.2021];

16. A ruling by the Supreme Court of the United States: "Craig v. Harney", 19.05.1947; https://supreme.justia.com/cases/federal/us/331/367/ [last seen 16.10.2021];

17. A ruling by the Supreme Court of the United States of America: In re Sawyer, June 29, 1959; https://supreme.justia.com/cases/federal/us/360/622/ [last seen 16.10.2021];

18. A ruling by the Supreme Court of the United States of America: "Gentile v. Nevada", 27.06.1991; https://supreme.justia.com/cases/federal/us/501/1030/ [last seen 14.10.2021]; 
19. A ruling by the Supreme Court of the United States of America: "Sacher v. United States of America", March 10, 1952; https://supreme.justia.com/cases/federal/us/343/1/ [last seen 14.10.2021];

20. A ruling by the Connecticut Court of Appeal: Notopoulos v. Statewide Grievance, 05.10.2004; https:/caselaw.findlaw.com/ct-court-of-appeals/1057176.html[last seen 14.10.2021];

21. A ruling by the Supreme Court of the United States of America: "Roth v. United States of America", 24.06.1957; https://www.oyez.org/cases/1956/582[last seen 14.10.2021];

22. A ruling by the Supreme Court of the United States of America: "Baggett v. Bullitt", 1.06.1964; https://supreme.justia.com/cases/federal/us/377/360/ [last seen 14.10.2021];

23. A ruling by the Supreme Court of the United States of America: "Kolender v. Lawson", 2.05.1983; https://supreme.justia.com/cases/federal/us/461/352/ [last seen 14.10.2021];

24. A ruling by the Supreme Court of the United States of America: Ginzburg v. United States of America, 7.12.1965; https://www.oyez.org/cases/1965/42[1ast seen 14.10.2021];

25. A ruling by the European Court of Human Rights: "Di Giovanni v. Italy", 9.07.2013;

26. A ruling by the European Court of Human Rights: "Kyprianou v. Cyprus", 15.12.2005;

27. A ruling by the European Court of Human Rights: "Kudeshkina v. Russia”, 26.02.2009;

28. A ruling by the European Court of Human Rights: "Prager and Oberschlick v. Austria", 26.04.1995;

29. A ruling by the European Court of Human Rights: "Perucci v. Italy", 30.06.2015;

30. A ruling by the European Court of Human Rights: "Marian Maciejewski v. Poland", 13.01.2015;

31. A ruling by the European Court of Human Rights: "Campos Damaso v. Portugal", 24.04.2008;

32. A ruling by the European Court of Human Rights: "Turanshau and Julie v. France", 24.11. 2005;

33. A ruling by the European Court of Human Rights: "Worm v. Austria", 29.08.1997;

34. A ruling by the European Court of Human Rights: "Nikula v. Finland", 21.03.2002;

35. A ruling by the European Court of Human Rights: "Schopfer v. Switzerland", 20.05.1998;

36. A ruling by the European Court of Human Rights: "Vajnai v. Hungary", 8.10.2008;

37. A ruling by the European Court of Human Rights: "Cumpana and Mazare against Romania", 17.12.2004;

38. A thesis by Eva Gotsiridze on "Freedom of Expression in the Context of a Fair Balance of Conflicting Values (according to the jurisprudence of the European Convention on Human Rights and the Court of Strasbourg)", International Law Institute - TSU 2007;

39. 39. Guide on Article 10 of the European Convention on Human Rights, Freedom of Expression, Updated om 31 August 2020, Council of Europe/European Court of Human Rights, 2021;

40. Gvantsa Tsulukidze, Rafiel Kakabadze, Veriko Berekashvili, "Freedom of Expression and Protection of Judicial Independence and Impartiality", Georgian Democratic Initiative (GDI) 2020;

41. Case law in the United States and Europe, Chapter II, Liberty Institute, 2005;

42. EMC Criticism of Ioseb Jachvliani's legislative initiative for "Insulting Religious Feelings", 2016, https://socialjustice.org.ge/ka/products/emc-s-kritika-religiuri-grdznobebis-sheuratskhqofis-sakitkhze-iosebjachvlianis-sakanonmdeblo-initsiativaze [last seen 24.09.2021;

43. Article 19 Background Paper on Freedom of Expression and Contempt of Court, International Seminar on Promoting Freedom of Expression With the Three Specialized International Mandates. 29-30 November, 2000; 
44. Freedom of Expression in Georgia, GDI, 2020;

45. Giorgi Beraia, "The Issue of Restriction of Freedom of Expression in the Name of Protecting the Authority of the Judiciary: Theory and Practice of National Courts, the European Court of Human Rights, the Supreme Court of the United States, and the UN Human Rights Committee, Review of Constitutional Law", XI, 2017;

46. Hon. Marilyn L. Huff, The Effects of Public Criticism of the Judiciary on Judicial Independence, U.S. Federal Judges Association, 2018, p.2. https://www.federaljudgesassoc.org/egov/documents/1539117619_2837.pdf [last seen 24.09.2021];

47. Eva Gotsiridze, "Restriction of Freedom of Expression to Protect the Authority and Impartiality of the Court (Review of the Jurisprudence of the Strasbourg Court) Law and the World", N13, 2019;

48. Attorney-General v Times Newspapers Ltd: HL 1973;

49. Consultant Editor C.J. Miller and David Perry QC, Miller on Contempt of Court, fourth edition, 2018;

50. Leach, Taking a Case to the European Court of Human Rights, Fourth Edition, Student Version, 2017;

51. First Amendment to the US Constitution, https://www.law.cornell.edu/constitution/first_amendment [last seen 24.09.2021];

52. Law of Georgia on Freedom of Speech and Expression. June 24, 2004;

53. Law of Georgia on Assemblies and Demonstrations. June 12, 1997. 